\title{
POŁOŻENIE MNIEJSZOŚCI NARODOWYCH W SERBII - OCHRONA PRAWNA I KONFLIKTY
}

\author{
WPROWADZENIE
}

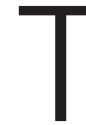

ematyka ochrony praw człowieka i mniejszości narodowych jest obecnie szeroko dyskutowana w Republice Serbii, co wiąże się między innymi z chęcią jej przystąpienia do Unii Europejskiej. Serbia pod względem liczby mniejszości narodowych na swoim terytorium jest państwem heterogenicznym. Wśród 8 mln obywateli Serbii wyróżnić możemy około 30 narodowości, a w autonomicznym okręgu Wojwodiny na 2 mln mieszkańców przypada aż 26 mniejszości narodowych. Celem niniejszego artykułu jest przedstawienie zarówno zarysu systemu ochrony prawnej mniejszości obowiązującej w Serbii, jak i punktów zapalnych dotyczących wybranych grup narodowościowych.

Mniejszości narodowe w Serbii stanowią 13,47\% jej mieszkańców (nie uwzględniając Kosowa). Według spisu ludności przeprowadzonego w 2002 r. do najliczniejszych grup narodowościowych należą: Serbowie 82,86\%, Węgrzy 3,91\%, Bośniacy 1,81\% i Romowie 1,44\%. Znaczny odsetek stanowią: Chorwaci 0,94\%, Czarnogórcy 0,92\%, Albańczycy 0,82\%, Słowacy 0,79\%, Wołosi 0,53\%, Rumuni 0,46\%, Macedończycy 0,34\%, Bułgarzy 0,27\%, Muzułmanie 0,26\% i Rusini $0,21 \%$. Podczas gdy mniejszości takie, jak: Słoweńcy 0,07\%, Ukraińcy 0,07\%, Goranie 0,06\%, Niemcy 0,05\%, Czesi 0,03\%, Rosjanie 0,03\%, Żydzi, Egipcjanie, Buniewcy, Šokci, Aškalije1, Grecy, Turcy, Cin-

Mgr Anna JAGIEŁŁO-SZOSTAK jest doktorantką w Instytucie Studiów Międzynarodowych na Wydziale Nauk Społecznych Uniwersytetu Wrocławskiego. annajagiello83@gmail.com

\section{.....}

Egipcjanie (serb. Egipćani) - mniejszość ta uważana jest za potomków zalbanizowanych Romów z Kosowa i posługuje się językiem albańskim. Przypuszcza się, iż ich przodkowie przywędrowali na Półwysep Bałkański z Egiptu.

Buniewcy - słowiańska grupa narodowościowa wywodzącą się z terenów Dalmacji (Chorwacja) i zachodniej Hercegowiny (Bośnia i Hercegowina). Obecnie zamieszkują Beczkę region Autonomicznego Okręgu Wojwodiny w północnej Serbii oraz północne Węgry. 
cari² $^{2}$ mają niewielką reprezentację. Odrębną grupę stanowią obywatele podający się za Jugosłowian - stanowią 1,08\% społeczeństwa ${ }^{3}$.

W Autonomicznym Okręgu Wojwodina, oprócz Serbów, zamieszkują następujące mniejszości: Węgrzy, Chorwaci, Słowacy, Czarnogórcy, Rumuni, Rusini, Ukraińcy, Muzułmanie, Buniewcy, Šokci, Niemcy, Macedończycy, Albańczycy, Słoweńcy, Romowie, Czesi, Bułgarzy, Wołosi, Aškalije, Żydzi, Grecy i Polacy. W Wojwodinie 65,05\% ludności stanowią Serbowie, a 14,28\% Węgrzy.

W Serbii istnieje 169 gmin (przeciętnie po 50 tys. mieszkańców), z których 68 jest multietnicznych (w Wojwodinie znajduje się w sumie 41 multietnicznych gmin ${ }^{4}$, a 27 na terenie Serbii Centralnej). Warto wspomnieć, że gmina uznawana jest za multietniczną wtedy, gdy 5\% jej populacji stanowi jedna mniejszość lub 10\% populacji danej gminy stanowią różne mniejszości narodowe ${ }^{5}$.

\section{OCHRONA PRAWNA}

Do podstawowych dokumentów chroniących prawa mniejszości narodowych w Republice Serbii należą: Konstytucja Republiki Serbii (2006), Statut Autonomicznego Okręgu Wojwodiny (1991), Ustawa o ochronie praw i wolności mniejszości narodowych (2002), Ustawa o urzędowym zastosowaniu języka i pisma (1991), Ustawa o podstawach systemu edukacji i wykształcenia (2004), Ustawa o samorządzie lokalnym (2002/06/07), Ustawa o umocnieniu kompetencji okręgu autonomicznego (tzw. Omnibus zakon), ustawa o informacji publicznej (2003), Ustawa o wyborze posłów narodowych (2002) oraz Ustawa o Kościołach i wspólnotach religijnych (2006). Ponadto Serbia podpisała bilateralne umowy z Chorwacją, Macedonią, Rumunią i Węgrami, które chronią prawa tych mniejszości w Serbii.

W najnowszej Konstytucji z 2006 r. w art. 1 Republika Serbii zdefiniowana została jako: „demokratyczne państwo wszystkich obywateli”, w przeciwieństwie do Konstytucji z 1990 r., w której istniał zapis, iż Serbia jest: „państwem narodu serbskiego i wszystkich obywateli”, co stawiało w gorszej pozycji inne narodowości niż serbska. Ustawa najwyższa jest gwarantem ochrony kolektywnych i indywidualnych praw człowieka i mniejszości narodowych, a według niej obywatele są równi bez względu na ich rasę, płeć, urodzenie, język, przynależność narodową, religię i przekonania polityczne.

Art. od 75 do 81 Konstytucji dotyczą mniejszości narodowych i obejmują zakaz dyskryminacji (art. 76), równość w wykonywaniu prac publicznych (art. 77), przedsięwzięcie akcji afirmatywneje (art. 78), prawo do zachowania odrębności narodowej (art. 79), ......

Šokci - naród, który zamieszkuje głównie Serbię, Chorwację i Węgry. W Chorwacji Šokci uważani są za etniczną grupę chorwacką. W Serbii mają status odrębnej mniejszości narodowej. Mniejszość ta jest wyznania katolickiego i posługuje się językiem serbskim.

Aškalije - mniejszość ta uważana jest za potomków zalbanizowanych Romów z Kosowa i posługuje się językiem albańskim. Przypuszcza się, że ich przodkowie przywędrowali na Półwysep Bałkański z Palestyny.

2 Cincari-romańska ludność, która przybyła na tereny dzisiejszej Serbii w XVIII w. z terenów Epiru, Tesalii, Albanii i Macedonii. Posługują się językiem cincarskim.

з Републички завод за статистику Србије, Попис становништва, домаћинства и станова у 2002, Београд 2003, s. $14-15$

4 Ustawa o samorządzie lokalnym reguluje prawo w gminach wielonarodowych.

5 N. Gojković, Sistem zaštite manjina u Republici Srbiji, [w:] Konrad Adenauer Stifung, www.kas.de/upload/auslandshomepages/serbien/Gojkovic_pred.pdf, 14 maja 2009 r.

$6 \quad$ Akcja afirmatywna inaczej dyskryminacja pozytywna - polityka państwa polegająca na stworzeniu rozmaitych ułatwień dla członków grup, które wcześniej podlegały dyskryminacji. 
prawo do zrzeszania, prawo do współpracy z rodakami z innych państw (art. 80) oraz prawo do rozwijania ducha tolerancji (art. 81). Ponadto Konstytucja reguluje prawa dotyczące swobody wyrażania tożsamości narodowej, prawa do różnorodności, prawa do informacji, kultury, edukacji oraz użycia własnego języka. Ustawa zakazuje wywoływania rasowych, religijnych i narodowościowych nienawiści ${ }^{7}$.

Kolejny dokument, Statut Autonomicznego Okręgu Wojwodiny z 1991 r., reguluje dodatkowo sytuację językową w wieloetnicznej Wojwodinie. Znajduje się w nim zapis, w którym oprócz praw mniejszości narodowych, wyznaczone są języki urzędowe Okręgu: serbski, chorwacki, węgierski, słowacki, rumuński i rusiński.

Ustawa o ochronie praw mniejszości narodowych przyjęta została jeszcze w czasie istnienia Federacyjnej Republiki Jugosławii (dalej SRJ)9 w 2002 r. i od tamtego czasu nie została wprowadzona żadna inna ustawa dotycząca mniejszości narodowych. Jest ona oparta na standardach zaczerpniętych z Ramowej Konwencji o ochronie mniejszości z 1998 r. ${ }^{10}$ oraz z Europejskiej Konwencji o językach regionalnych i mniejszościowych ${ }^{11}$, przyjętej przez Serbię w 2005 r.

W Ustawie o ochronie praw mniejszości w art. 2 znajduje się pojęcie mniejszości narodowej, które definiuje ją jako grupę społeczną, która ma długą i silną więź z terytorium SRJ (obecnie RS - Republika Serbii) oraz cechy takie, jak: język, kultura, przynależność narodowa lub etniczna, pochodzenie oraz wyznanie, które wyróżniają ją od większości obywateli.

Ustawa ta oparta jest na podstawowych zasadach, jak: zakaz dyskryminacji, równość, wolność słowa, obowiązek poszanowania porządku konstytucyjnego, zasad prawa międzynarodowego i moralności publicznej oraz ochrona nabytych praw ${ }^{12}$. Kolektywne prawa mniejszości narodowych realizowane są poprzez prawo do: ochrony tożsamości narodowej, zastosowania języka i pisma mniejszości, uznanie języka mniejszości za urzędowy tam, gdzie ich liczba w gminie wynosi 15\% populacji, prawa do pielęgnowania kultury i tradycji (co przejawia się w prawach do rozwoju języka i religii), prawa do nauki we własnym języku, prawa do użycia symboli narodowych, które nie mogą być identyczne z symbolami państwa, na terenie którego żyją.

Ustawa ta ponadto przewiduje tworzenie Krajowych Rad Mniejszości Narodowych, których członkowie są przedstawicielami danej mniejszości narodowej i mogą wychodzić z inicjatywami ustaw dotyczących mniejszości. Na uchwalenie czeka projekt Ustawy o krajowych radach mniejszości narodowych. Problem, jaki uwidocznił się wokół tego projektu, to definicja rady narodowej oraz stopień uczestnictwa w podejmowaniu decyzji w rządzie ${ }^{13}$. Mimo że ustawa ta nie obowiązuje jeszcze w Serbii, to pierwszą Radę utworzyła mniejszość węgierska w 2002 r., a następnie Rusini, Rumuni, Chorwaci, Słowacy, Buniewcy, Ukraińcy, Romowie, Boszniacy, Niemcy, Egipcjanie, Grecy, Macedończycy i Wołosi.

Ustav Republike Srbije, „Službeni glasnik RS”, br. 98/2006 r.

Статут Аутономне Покрајине Војводине, Службени лист, бр. 17/91 од 29.06.1991 r.

SRJ - Savezna Republika Jugoslavija, Federacyjna Republika Jugosławii. Państwo to utworzone zostało po rozpadzie Socjalistycznej Federalnej Republiki Jugosławii w 1992 r. i przetrwało do 2003 r. jako federacja Serbii i Czarnogóry.

10 Okvirna konvencija za zaštitu nacionalnih manjina, „Službeni list SRJ - Međunarodni ugovori”, br. 6/1998.

11 Zakon o reatifikaciji evropske povelje o regionalni mili manjinskim jezicima, „Službeni list SCG - Međunarodni ugovori", br. 18/2008.

12 Zakon o zaštiti prava i sloboda nacionalnih manjina, „Službeni list SRJ”, br. 11/2002.

13 Završen nacrt Zakona o Nacionalnim savetima nacionalnih manjina, 27.10.2008 r., [w:] Ministarstvo za ljudska i manjinska prava, www.humanrights.gov.yu, 13 maja 2009 r. 
W 2005 r. na mocy ustawy wprowadzona została instytucja ombudsmana, a od 2007 r. jest nim Sasza Janković14. Wcześniej, w grudniu 2002 r., w Wojwodinie wprowadzony został urząd okręgowego ombudsmana, który jest niezależnym i samodzielnym organem Autonomicznego Okręgu Wojwodiny. Jego zadaniem jest dbanie o ochronę i poprawę praw człowieka i wolności wszystkich obywateli zgodnie z Konstytucją i umowami międzynarodowymi ${ }^{15}$. W Okręgu tym istnieje także Rada do spraw stosunków międzyetnicznych.

Kolejnym przyjętym aktem jest Ustawa przeciwko dyskryminacji, która uchwalona została w kwietniu 2009 r. i definiuje między innymi pojęcie dyskryminacji16.

Mimo dostatecznej ochrony prawnej mniejszości zwrócić trzeba uwagę na istniejące sprzeczności między ustawami. Przykładem tego może być Ustawa o samorządzie lokalnym, w której istnieje zapis o zakazie publicznego używania symboli narodowych mniejszości, co jest w kolizji z art. 16 Ustawy o ochronie praw mniejszości, który mówi że członkowie mniejszości narodowych mają prawo wyboru i użycia symboli narodowych ${ }^{17}$. Drugi przykład stanowi gwarancja prawa do zakładania lokalnych stacji telewizyjnych i radiowych emitujących programy w językach mniejszości narodowych. Konstytucja i Ustawa o samorządzie lokalnym przewiduje powyższe rozwiązanie, podczas gdy Ustawa o radiofonii i telewizji o tej kwestii nie wspomina.

W Serbii w dalszym ciągu nierozwiązane kwestie dotyczą m.in.: położenia mniejszości albańskiej na południu Serbii, wzajemnych relacji mniejszości rumuńskiej i wołoskiej, mniejszości węgierskiej w Wojwodinie, położenia Romów oraz muzułmanów z Sandżaku.

Rozmieszczenie mniejszości narodowych w Serbii nie jest jednolite. W części południowej skoncentrowani są głównie Albańczycy. W części południowo-zachodniej państwa na terenie Sandżaku mieszka znaczna liczba Muzułmanów/Boszniaków¹8, a Wołosi skoncentrowani są w Serbii wschodniej. Najbardziej rozproszoną mniejszość stanowią Romowie.

\section{POŁOŻENIE MNIEJSZOŚCI NARODOWYCH}

\section{MNIEJSZOŚĆ ALBAŃSKA}

Mniejszość albańska skoncentrowana jest w gminach Medvedja, Preseva i Bujanovaca i liczy 120 tys. osób. Problemy z mniejszością albańską wynikają m.in. z zadawnionego konfliktu między Albańczykami i Serbami o Kosowo.

W 2005 r. Albańczycy domagali się autonomii dla 3 gmin, a w 2007 r. przedstawili program autonomii, w której zawarty jest aneks mówiący, że w wypadku zmiany granic Kosowa (co nastąpiło w lutym 2008 r., gdy Kosowo ogłosiło niepodległość) Albańczycy z południa Serbii będą żądali zjednoczenia tych gmin z Kosowem. Ponadto, stworzony w 2004 r. Koordynacyjny Organ do spraw Serbii Południowej, mający za zadanie integrację Albańczyków z resztą społeczeństwa, jest bojkotowany przez tę narodowość.

\section{..."}

14 Zasztitnik gradjana, www.zastitnik.gov.rs, 13 maja 2009 r.

15 Ibidem.

16 Spisak donetih zakona, Narodna skupština Republike Srbije, www.parlament.sr.gov.yu, 15 maja 2009 r.

17 Zakon o zaštiti prava i sloboda nacionalnih manjina, „Službeni list SRJ”, br. 11/2002.

18 Bośniak - mieszkaniec Bośni i Hercegowiny bez względu na wyznanie i narodowość. Boszniak - mieszkaniec Bośni i Hercegowiny pochodzenia muzułmańskiego. Podobnie nazwy narodowości Boszniak używa ludność pochodząca z BiH, Sandżaku, Czarnogóry i Kosowa muzułmańska ludność słowiańska żyjąca w enklawach narodowych w Turcji. Zob. A. Hofman-Pianka, Socjolingwistyczne aspekty współczesnego języka bośniackiego, Kraków 2000, s. 75. 
Uważają oni, że nie są informowani o wprowadzanych w nim zmianach oraz że nie spełnia on swojej funkcji ${ }^{19}$. Albańczycy uważają także, iż serbska policja stworzyła getto w Dolinie Preszeva (gdzie 3 gminy zamieszkuje mniejszość albańska). Rząd zaznacza jednak, że duży odsetek policjantów w tym regionie to Albańczycy. Ponadto, Ministerstwo Spraw Wewnętrznych razem z OBWE opracowało projekt pt. „Policja we wspólnocie lokalnej", a zagrożenie przemytem i terroryzmem wymusza stacjonowanie sił specjalnych w tym regionie. Dodatkowo sytuację pogarsza duże bezrobocie wśród tej mniejszości i jej zarzuty skierowane do rządu serbskiego, że nie robi on nic, by poprawić tu sytuację ekonomiczną ${ }^{20}$. W gminach tych język albański funkcjonuje jako urzędowy, a Albańczycy mają możliwość nauki w swoim języku oraz studiowania na Uniwersytecie Belgradzkim, gdzie działa Katedra Albanistyki.

\section{MNIEJSZOŚCI WOŁOSKA I RUMUŃSKA}

Problemy mniejszości wołoskiej i rumuńskiej rozpatrywać możemy na trzech płaszczyznach, tj. pochodzenia Wołochów i uznania ich za mniejszość narodu rumuńskiego zamieszkującego wschodnią Serbię, prawa do edukacji w języku rumuńskim oraz prawa do odprawiania mszy w języku rumuńskim, co w praktyce oznacza uformowanie diecezji Rumuńskiej Cerkwi Prawosławnej.

W Serbii Wołosi uważani są za ludność autochtoniczną i posiadają status mniejszości narodowej. Rumuni z kolei uważają, że jest to mniejszość rumuńska i popierają swoje argumenty tym, że język wołoski nie jest standaryzowany. Ponadto, Rada Narodowa Rumunów w Serbii ogłosiła rumuński językiem literackim Wołochów. Wśród przedstawicieli mniejszości wołoskiej nie ma zgody co do powyższych kwestii, co pogłębia spór między nimi. Część Wołochów i Serbowie zarzucają zarówno przedstawicielom mniejszości rumuńskiej, jak i Rumunii narzucanie im swojej tożsamości narodowej oraz „rumunizację”.

Uznawanie Wołochów za Rumunów Serbia postrzega jako zagrożenie dla swojej państwowości. Po pierwsze, coraz częściej Wołosi wybierają obywatelstwo rumuńskie, gdyż jest to kraj należący do UE. Po drugie, Wołosi wyjeżdżają do Rumuni, by tam kończyć szkoły, a później wracają jako mniejszość rumuńska. Po trzecie, coraz częściej Rumuni kupują domy letniskowe na wschodzie Serbii. Budzi to obawy Serbii o rumunizację państwa²1.

\section{MNIEJSZOŚĆ WĘGIERSKA W WOJWODINIE}

Według spisu ludności z 2002 r. Węgrzy w Wojwodinie stanowią 14,3\%. Mniejszość ta cieszy się najlepiej uregulowaną sytuacją prawną. Edukacja mniejszości narodowych w Wojwodinie prowadzona jest w szerokim zakresie. Uczniowie narodowości węgierskiej uczęszczają do szkół podstawowych i średnich, w których prowadzone jest nauczanie dwujęzyczne lub tylko w języku węgierskim. Nauczanie w tym języku prowadzone jest .....

19 Jug Srbije - platforma autonomie, B92, 27 grudnia 2005 r., www.b92.net; Serbia: Maintaining Peace in the Presevo Valley, „Europe Report” No. 186, 16 October 2007 r., International Crisis Group, www.crisisgroup.org; Problem integracije Albanaca na jugu Srbije, RTV Studio B, 22 września 2007 r., www.studiob.rs. i Pitanja bezbednosti na jugu Srbije, RTV Studio B, 12 sierpnia 2007 r., www.studiob.rs.

20 O. Zekić, Mladića i Hadžića tražimo na pogrešnom mestu, Borba, 17 maja 2009 r., www.borba.rs.

21 M. Albunović, Vlasi istočne Srbije-od asimilacije do rumunizacije, „Politika”, 18 maja 2009 r., s. 5 i Vlasi ili Rumuni, „Politika”, www.politika.rs, 13 maja 2009 r.

22 Zob.: A. Jagiełło, Mniejszość węgierska w Wojwodinie, [w:] W. Baluk, Z.J. Winnicki (red.), Badania wschodnie. Polityka wewnętrzna i międzynarodowa, Wrocław 2008. 
także w uczelniach wyższych w Suboticy, Somborze i Nowym Sadzie. W 29 (na 46 istniejacych) gminach w Wojwodinie językiem urzędowym jest język węgierskiej mniejszości narodowej23. Mimo to brak dwujęzycznych nazw miast, wsi, ulic, placów i instytucji w miejscowościach, w których populacja węgierska nie tworzy większości24.

W Wojwodinie często dochodzi do incydentów między Węgrami a Serbami. Jednym z problemów jest wypisywanie antywęgierskich haseł (Smrt Madjarima - „Śmierć Węgrom”) m.in. w Suboticy, Bečeju czy Sremskiej Kamenicy. Dochodziło także do bójek między młodzieżą serbską i węgierską w Suboticy, Kisaču, Bačkim Vinogradima czy w Temerynie ${ }^{25}$. Liderzy mniejszości węgierskiej uważają, że takich incydentów byłoby mniej, gdyby w policji tego regionu pracowało tylu Węgrów, ilu ich jest proporcjonalnie w populacji, czyli 15 a nie $5 \%{ }^{26}$. Podobna jest sytuacja w organach administracji Wojwodiny.

Obawę budzić mogą także ruchy nacjonalistyczne, tj. Młodzieżowy Ruchu 64 Żupani27 z Węgier. Na zebraniu w miasteczku Mali Iđoš w 2004 r. rozdawano mapy z nakreślonymi Wielkimi Węgrami, obejmującymi teren połowy Wojwodiny. Zebrani krzyczeli: „To są Węgry" (Ovo je Mađarska). Uczestnicy nie chcieli także, na żądanie policji, usunąć wywieszonej przez nich flagi Węgier ${ }^{28}$.

Ogłoszenie przez Kosowo niepodległości ${ }^{29}$ rozpoczęło dyskusje o dążeniu mniejszości węgierskiej do coraz szerszej autonomii, czego przykładem jest niedawna inicjatywa 3 partii tej mniejszości: Związku Węgrów Wojwodiny, Demokratycznej Partii Węgrów Wojwodiny i Demokratycznej Wspólnoty Węgrów Wojwodiny. W marcu 2008 r. ukazał się Wspólny Projekt Autonomii Partii Węgrów z Wojwodiny. Mniejszość węgierska nie dąży jednak do separatyzmu, ale jak wynika ze wspólnego projektu, do poszerzenia swoich praw w dziedzinie kultury, edukacji, publicznego dostępu do informacji i ku urzędowemu zastosowaniu języka i pisma.

\section{MNIEJSZOŚĆ ROMSKA}

Mniejszości pod względem terytorialnym w Serbii rozmieszczone są homogenicznie, jednak wyjątek stanowią Romowie, którzy osiedleni są na całym terytorium państwa. Według oficjalnego spisu ludności z 2002 r. mniejszość romska w Serbii jest czwartą grupą narodową pod względem liczebności i liczy 108 tys. osób ${ }^{30}$. Szacuje się jednak, iż mniejszość ta może liczyć nawet 400-500 tys. osób. Najwięcej Romów mieszka w Belgradzie, Wojwodinie i Centralnej Serbii. W Belgradzie mieszka 36 tys. Romów, a $13 \%$ z nich nie posiada żadnego dokumentu tożsamości ${ }^{11}$.

\section{$\cdots \cdots$}

23 Nacjonalne manjine u SCG, op. cit., s. 23.

24 B. Stojković, Cultural Policy responses to cultural diversity of Serbia, [w:] G. Bašić (red.), Demokratija i multikulturalnost u Jugoistočnoj Evropi, Beograd 2003, s. 453.

25 Ljudska Prava u Srbiji i Crnoj Gori 2004, op. cit., s. 311.

26 Ibidem, s. 310.

27 Młodzieżowy Ruch 64 Żupani (węg. 64 Vármegye Ifjúsági Mozgalom, serb. Omladinski pokret 64 Županije) - węgierska neonazistowska organizacja, która w 2004 r. w Beczeju w Wojwodinie założyła swoją filię. Ruch ten widzi potrzebę odłączenia się terenów historycznie należących do Węgier i przyłączenia ich do federacyjnego państwa, co może być osiągnięte środkami pokojowymi jak i przemocą. R. Kukobati, Nacionalisti Sajnaju veliku Mađarsku, „Glas javnosti” z 16.06.2004, http://arhiva.glas-javnosti.co.yu 10.05.2008 r. i 64 Vármegye Ifjúsági Mozgalom, http://www.hvim.hu/, 10.05.2008r. Ljudska Prava u Srbiji i Crnoj Gori 2004, op. cit., s. 311-312.

29 Kosowo ogłosiło niepodległość 17.02.2008 r.

30 Romowie często ukrywają swoją tożsamość narodową, czego przyczyną jest ich dyskryminacja. Świadczą o tym statystyki: 1948 r. - 52 tys., 1953 r. - 58 tys., 1961 r. - 9 tys.!, 1991 r. - 140 tys.

31 Radna grupa za zbrinjavanje Roma, „Borba”, www.borba.rs, 7.04.2009 r. 
W kwietniu 2003 r. w ramach działań Ministerstwa Praw Człowieka i Mniejszości Republiki Serbii utworzony został Sekretariat ds. Narodowej Strategii Romskiej. W kwietniu 2009 r. przyjęta została Strategia poprawy położenia Romów (dalej SRNS). Prace SRNS wspierają takie organizacje jak ONZ, Szwedzka organizacja ds. rozwoju międzynarodowego, Fundusz ds. społeczeństwa otwartego, misja OBWE w Serbii, Rada Europy i UNHCR. Celem Sekretariatu jest koordynacja pomocy dla Romów w ramach planu Dekady inkluzji Romów przewidzianego na lata 2005-2015 w dziedzinie edukacji, zamieszkania, zdrowia, zatrudnienia ${ }^{32}$. Prawa te są zawarte także w następujących dokumentach: Strategia poprawy edukacji Romów, Plan integracji Romów - edukacja, zatrudnienie, zamieszkanie i ochrona zdrowia ${ }^{33}$ oraz w umowach i rezolucjach międzynarodowych przyjętych przez Serbię.

Romowie są najbardziej dyskryminowaną grupą społeczną w Serbii, której statut mniejszości narodowej przyznano dopiero w 2002 r. Problemy, z jakimi się borykają, to: brak pracy, złe położenie ekonomiczne, osiedla bez infrastruktury, analfabetyzm, złe traktowanie przez policję, pasywność policji w incydentach z Romami, niski stopień wykształcenia oraz uprzedzenia ze strony większości obywateli. Serbia jest pierwszym krajem regionu, który chce wprowadzić prawną ochronę Romów ${ }^{34}$.

Sandżak jest wielonarodowościowym regionem położonym na pograniczu Serbii i Czarnogóry ${ }^{35}$. Największą grupą narodową na terenie Sandżaku są muzułmanie, którzy stanowią 60\% ogółu mieszkańców i skoncentrowani są w 6 gminach w południowej Serbii - w Novym Pazarze, Tutinie, Sjenicy, Priboju, Prijepolju i Novej Varoszy. Sandżak jest jednym z najbiedniejszych regionów Serbii, który boryka się z problemami takimi, jak: wysokie bezrobocie, wysoki odsetek migracji do krajów ościennych, słabo rozwinięta infrastruktura, sieć instytucji naukowych, kulturowych i zdrowotnych.

W 1961 r. władze Jugosławii dopuściły, by ludność z obszaru Bośni i Hercegowiny określała siebie w spisach powszechnych jako „muzułmanin w sensie etnicznym”. Dodatkowo we wstępie do Konstytucji Jugosławii z 1963 r. uznano 3 narody: serbski, chorwacki i muzułmański, a w 1968 r. władze uznały naród bośniacki. Sprawa muzułmanów zaszła jednak dalej. W 1992 r. odbyło się referendum w sprawie samostanowienia Sandżaku, a w 1993 r. muzułmanie z Sandżaku ogłosili memorandum w sprawie statusu tego regionu i jego powrotu do granic sprzed 1912 r., czyli sprzed podziału pomiędzy Serbię i Czarnogórę. W 1993 r. podczas obrad Parlamentu Boszniackiego postanowiono, iż określenie muzułmanin zastąpi nazwa Boszniak ${ }^{36}$.

\section{$\ldots . .$.}

Sekretarijat za romsku nacionalnu strategiju, 23.01.2009 r., [w:] Ministarstvo za ljudska i manjinska prava, www.humanrights.gov.yu, 13.05.2009 r.

33 Ibidem.

34 Konferencja: EU - Republic of Serbia. Enhanced Permanent Dialogue, Palace of the Republic of Serbia, Belgrad, 12 maja 2009 r.

35 Sandżak został odłączony od bośniackiego elajetu decyzją kongresu berlińskiego z roku 1878. Do 1912 r. wchodził w skład Imperium Osmańskiego. Po wojnach bałkańskich podzielony został między Serbię i Czarnogórę. Obecnie do Serbii należą gminy: Novi Pazar, Tuzin, Sjenica, Prijepolje, Nova Varoš, Priboj, a do Czarnogóry: Pljevlja, Bielo Polje, Berane, Andrijevica, Rožanje i Plav. Zob. S. Bierko (red.), Sandžak identitet u proceptu starog i novog, Beograd 2008, s. 51 i in.

36 A. Parzymies (red.), Muzułmanie w Europie, Warszawa 2005, s. 118 i M. Waldenberg, Rozbicie Jugosławii. Jugosłowiańskie lustro międzynarodowej polityki, Warszawa 2005, s. 156-157. 
Destabilizacja Sandżaku wynika z silnego poczucia tożsamości narodowej Boszniaków, co przejawia się w uznawaniu wartości islamu oraz zwracaniu uwagi na odmienność języka bośniackiego ${ }^{37}$. Ponadto, Reis-ul-ulema Islamskiej Wspólnoty Bośni i Hercegowiny Mustafa Cerić38 na spotkaniu z wiernymi w Tuzinie stwierdził, że Boszniacy z Bośni i Sandżaku są jednym narodem, a ich duchowym centrum jest Sarajewo. Niechęć Serbii do Boszniaków wyrażona jest m.in. przez utrudnianie zatrudnienienia osób, które posiadają obywatelstwo serbskie i sarajewskie dyplomy ukończenia studiów wyższych. Należy zwrócić też uwagę na negatywny stosunek Cerkwi Prawosławnej oraz Serbskiej Partii Radykalnej (SRS) do tej mniejszości ${ }^{39}$.

\section{PODSUMOWANIE}

W Serbii nastąpiła znaczna poprawa w zakresie przestrzegania praw mniejszości narodowych, ale $w$ dalszym ciągu istnieją problemy $w$ relacjach międzyetnicznych i we wprowadzaniu aktów prawnych, które regulują te prawa. W najlepszym położeniu znajdują się mniejszości narodowe zamieszkujące Wojwodinę, gorsza jest sytuacja w Centralnej Serbii, południowej i wschodniej.

Przeszkodę w polepszeniu wzajemnych relacji między mniejszościami stanowią zbyt małe dotacje państwowe na instytucje mniejszości narodowych oraz duży dystans etniczny Serbów w stosunku do Albańczyków, Chorwatów i Muzułmanów, czego przyczyną są doświadczenia wojenne z lat dziewięćdziesiątych XX wieku oraz konflikt o Kosowo.

\section{THE POSITION OF NATIONAL MINORITIES IN SERBIA \\ - THEIR LEGAL PROTECTION AND CONFLICTS}

\section{Summary}

National minorities constitute almost fourteen percent of the population of the Republic of Serbia. The main aim of the article is to present the mechanism for the protection of minority rights in Serbia. The author also compares them with the corresponding European standards. Moreover, she discusses in detail some of the major political, cultural, educational, linguistic, and social problems of the minorities living in this territory.

\section{$\cdots \cdot \cdot$}

Język bośniacki używany jest przez Bośniaków z Bośni i Hercegowiny i Sandżaku. W wyniku islamizacji Bośni i Hercegowiny przez Imperium Osmańskie w języku bośniackim na stałe zadomowiły się cechy orientalne. W leksyce widoczne jest to w onomastyce, terminologii religijnej oraz w nazwach zawodów i przedmiotów gospodarstwa domowego. Język bośniacki ma także odrębne cechy charakterystyczne w stosunku do języka chorwackiego i serbskiego w systemie akcentowym, fonetyce, morfologii i składni. A. Hofman-Pianka, Socjolingwistyczne aspekty współczesnego języka bośniackiego, s. 92-114.

38 Reis-ul-ulema - tytuł religijnego zwierzchnika muzułmańskiego w Bośni i Hercegowinie oraz muzułmanów pochodzących z Bośni. Od 1993 r. funkcję tę pełni Mustafa Cerić.

39 Serbia's Sandzak: Still Forgotten, „Europe Report” No. 162, 8 April 2005, International Crisis Group, www.crisisgroup.org; S. Novosel, Sarajevo je duhovni centar svih Bošnjaka, "Danas”, 19 maja 2009 r. i S. Biševac, „Sumnjive” sarajevske diplome, „Danas”, 11 maja 2009 r.; Cerić: Krše se prava muslimana, B92, www.b92.net, 19 maja 2009 r. 
The article thus deals with the following minorities: Albanians who live in southern Serbia, Muslims from Sanjak, Hungarians from Vojvodina (the second biggest minority in Serbia), as well as the Vlahos, Romanians and Roma people, who are scattered all over the country. All of these ethnic minorities are indeed strongly demanding legal protection from the state. The issues of their distribution and status in the light of their ethnicity versus the global society are also tackled in the article.

Keywords: Serbia, national minority, protection of minority rights 